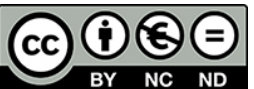

\title{
Business Strategies of the Companies listed on the FTSE MIB index of Borsa Italiana Stock Exchange
}

\author{
Riccardo Profumo \\ CSE-Crescendo, Milan, Italy \\ www.cse-crescendo.com
}

\section{ABSTRACT}

The aim of the research is to provide a gross evaluation of the entrepreneurial system's ability to create new industries.

The research focuses on the most important Italian firms: the companies listed on the FTSE MIB index of Borsa Italiana.

The way to comprehend the entrepreneurial system's capability to create new industries, is by understanding the innovation level they are able to generate by the strategic planning activity. The model used for this research is the "Value Life Cycle Model" developed by Mr Francesco Zanotti.

The overall result shows that the FTSE MIB Companies don't have a strategic goal of creating new industries. The innovation level inside the business strategies designed by the FTSE MIB companies is generally very low.

KEYWORDS

Industry, Attractiveness, Innovation, Industry Attractiveness,

Entrepreneurial Strategy, Entrepreneurial innovation, FTSE MIB, Value Life Cycle Model

\section{THE CONTEXT}

The necessity of the construction of a new economic and social system is absolutely shared by a lot of contemporary observers.

Without doubt, the entrepreneurial system plays a key role for the economic growth and social development.

The creation of new industries is crucial: radically new products (or services) are the only way to create new industries and developing markets.

The aim of the research is to provide a gross evaluation of the entrepreneurial system's ability to create new industries.

The way to comprehend the entrepreneurial system's capability to create new industries, is by understanding the innovation level they are able to generate by the strategic planning activity.

The business strategy undertaken by the companies show the future they are planning and the economic and social development we can expect from them.

In other words, the innovation level inside the business strategies designed by the companies, shows their capability to create new industries and markets. 
THE OBJECT OF THE ANALYSIS

The research focuses on the most important Italian firms: the companies listed on the FTSE MIB index of Borsa Italiana.

These companies are the most influential for the national economic growth and social development. It is reasonable to expect from their strategic plans the maximum level of innovation capability.

The research is based only on public information. The sources used were the Business Plan's documents published on the corporate web sites. Only 26 companies (the total number of companies listed on the FTSE MIB index of Borsa Italiana are 40) publishes their Business Plan. The research is therefore limited to the following companies and documents:

TABLE 1 - Business Plans analyzed

\begin{tabular}{|c|c|c|}
\hline \multicolumn{3}{|c|}{ Business Plans analized } \\
\hline & Company & Business Plan \\
\hline 1 & $A 2 A$ & $\begin{array}{l}\text { A2A roadmap: deleveraging and costcutting for a sustainable } \\
\text { growth }\end{array}$ \\
\hline 2 & ANSALDO STS & Investor Meeting 2013 - Key elements of Ansaldo STS strategy \\
\hline 3 & ATLANTIA & Supporting global growth \\
\hline 4 & BANCA MONTE DEI PASCHI DI SIENA & Piano Industriale 2012-15 <<Rilancio 2015〉> \\
\hline 5 & BANCA POPOLARE DELL'EMILIA ROMAGNA & Gruppo BPER Piano Industriale 2012-2014 \\
\hline 6 & BANCA POPOLARE DI MILANO & $\begin{array}{l}\text { La forza del cambiamento: II Piano Industriale del Gruppo } \\
\text { BPM 2012-2015 }\end{array}$ \\
\hline 7 & BANCO POPOLARE & Banco Popolare Piano Industriale 2011-13/15 \\
\hline 8 & DIASORIN & Investor Day \\
\hline 9 & ENEL & 2012 Results 2013-2017 Plan \\
\hline 10 & ENEL GREEN POWER & Enel Green Power's 2013 - 2017 business plan \\
\hline 11 & ENI & Eni 2013-2016 Strategy \\
\hline 12 & FIAT & $\begin{array}{l}\text { Creating our own destiny: a solid, united Group to reshape } \\
\text { and reposition the auto business in Europe }\end{array}$ \\
\hline 13 & FINMECCANICA & Strategy and Actions Plans \\
\hline 14 & GENERALI & Generali Goup - Investor Day \\
\hline 15 & INTESA SAN PAOLO & Intesa San Paolo Piano d'Impresa 2011-13/15 \\
\hline 16 & LUXOTTICA GROUP & Luxottica - A long way to grow \\
\hline 17 & PIRELLI \& C & Industrial Plan \\
\hline 18 & PRYSMIAN & Prysmian Group - Company Presentation \\
\hline 19 & SAIPEM & Operational Review \& Strategy Update \\
\hline 20 & SNAM & 2013-2016 Strategy \& Targets \\
\hline 21 & STMICROELECTRONICS & STMicroelectonics announces a new strategic plan \\
\hline 22 & TELECOM ITALIA & 2012 Full Year Preliminary Results and 2013-2015 Plan Outline \\
\hline 23 & TENARIS & Investor presentation \\
\hline 24 & TERNA & 2013-2017 Strategic Plan \\
\hline 25 & UBI BANCA & UBI Banca Piano Industriale 2011-13/15 \\
\hline 26 & UNICREDIT & UniCredit Strategic Plan \\
\hline
\end{tabular}




\section{THE INSTRUMENTS USED: THE MODEL AND THE METHODOLOGY FOR THE ANALYSIS}

THE “VALUE LIFE CYCLE” MODEL

The model used for this research is the "Value Life Cycle Model" developed by Mr Francesco Zanotti.

The "Value Life Cycle Model" describes the degeneration process of an industry. The model identifies five macro-steps from the industry generation to its competitive death.

The process described in the "Value Life Cycle Model" considers five macrocategories of business strategies at business unit's level:

\section{Entrepreneurial Strategy}

Design of a radically new business unit, especially in terms of product/service, in order to generate new industry.

2. Quality Strategy

The reiterated and continuous research of quality development.

3. Efficiency Strategy

Research of internal efficiency and low sales price.

4. Communication Strategy

Development of the brand and of the product/service demand, between competitors with same levels of quality and efficiency.

\section{Support Strategy}

Use or research of external instruments outside of the competitive environment (usually provided by institutions such as local government).

The "Value Life Cycle Model" suggests the best mix of business strategies is to focus on a continuous and reiterated effort in order to generate new industries and markets (the entrepreneurial strategy).

The best mix of business strategies (at business unit level) uses all the strategy categories in the proportion described in the following image: 
FIGURE 1 - "Value Life Cycle Model": best mix of strategies

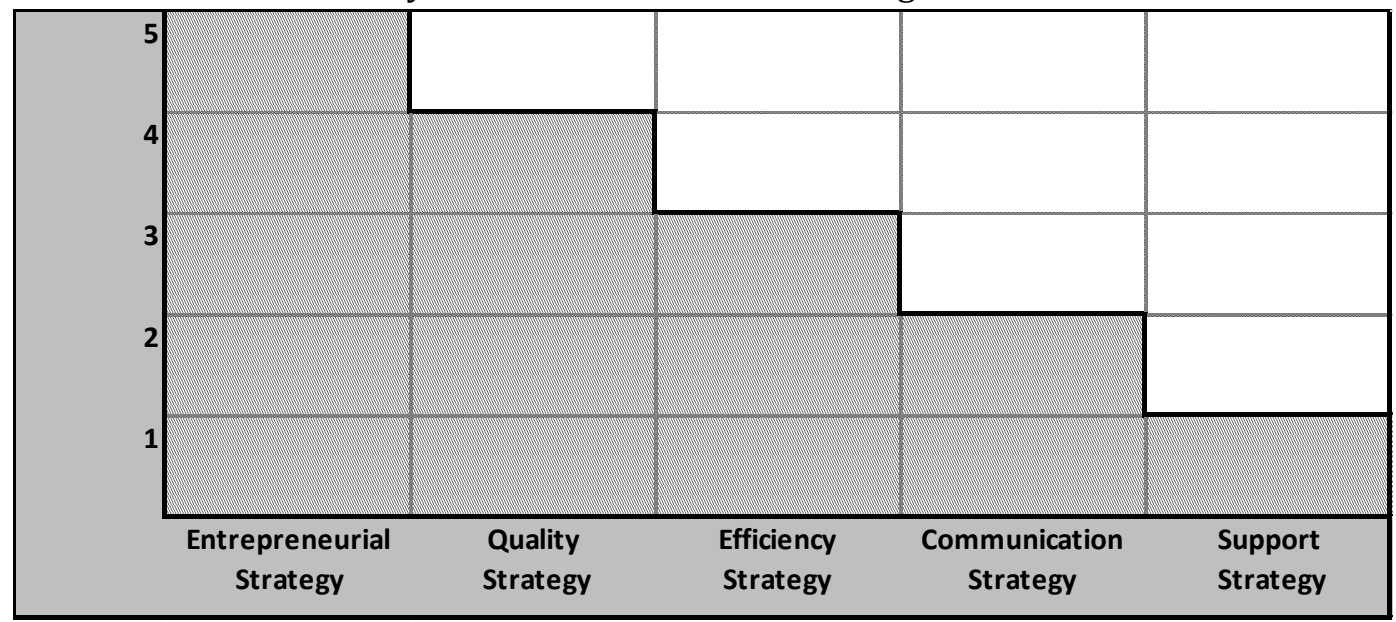

Apart from entrepreneurial strategy, all strategies (quality, efficiency, communication and support) are designed to manage the competition created inside the industry.

The placement of the strategies (developed by the industry players) inside the five macro-categories above establishes:

- the attractiveness of the industry ;

- the capacity to generate cash flow by the companies.

For other details on the model's theory we refer to the article "Quantum Governance of Development" of Mr Francesco Zanotti.

\section{THE METHODOLOGY FOR THE ANALYSIS}

The "Value Life Cycle Model" has been used as the cognitive scheme to analyse the business strategy stated in the Business Plans of the companies listed on the FTSE MIB index of Borsa Italiana.

The methodology used in this research places the business strategies extracted from the business plans, into the 5 strategy categories of the "Value Life Cycle Model" (entrepreneurial, quality, efficiency, communication and support). 


\section{THE LIMITS OF THE BUSINESS PLANS INFORMATION}

\section{THE DESCRIPTION OF THE BUSINESS UNITS}

For the correct application of the methodology, it is fundamental that the description of the Business Unit in all its five drivers (products, customers, customer's needs satisfied, technology, value chain) is complete.

In their Business Plans, lot of companies do not fulfill this requirement as they do not fully describe each driver.

When the business units are not deeply defined, the business strategies are generically and simply declared.

In these cases, we can only look at the company as one business unit itself and consider the strategic actions valid for all the company's business areas.

\section{THE CORPORATE STRATEGIES}

The "Value Life Cycle Model" describes the life cycle inside an industry/business unit. The analysis doesn't consider the strategies at a corporate level, such as Group Restructuring, Governance Model Evolution, M\&A or Capital Management.

Other strategic actions (Organization Model, Human Resource Policies, Risk Management, Social Responsibility, Environment Sustainability) are classified inside the model by their evident implications on the business unit's structure. 


\section{THE STRATEGY IDENTIFIED AND THEIR ALLOCATION ON THE ANALYSIS MODEL}

We read all the business plans and underlined the strategy and the action plans originated.

We pointed out only the business strategy and the following action.

TABLE 2 - Entrepreneurial Strategy from the Business Plans analyzed

\begin{tabular}{|r|l|}
\hline \multicolumn{2}{|c|}{ Business Strategies Classification } \\
\hline 1 & \multicolumn{1}{|c|}{ Entrepreneurial strategy } \\
\hline 2 & $\begin{array}{l}\text { Development of new stream of business, innovation in offering structure, widening offering structure, } \\
\text { product line extension; }\end{array}$ \\
\hline 2 & New products introduction, development of new products, new products innovation; \\
\hline 3 & New service model development, innovative services introduction; \\
\hline 4 & Internationalization, geographic diversification, geographic expansion; \\
\hline 5 & Business model evolution; \\
\hline 6 & New pricing model; \\
\hline 7 & Exit from non strategic segment, discontinuity in specified business areas; \\
\hline
\end{tabular}

TABLE 3 - Quality Strategy from the Business Plans analyzed

\begin{tabular}{|r|l|}
\hline \multicolumn{2}{|c|}{ Business Strategies Classification } \\
\hline 1 & \multicolumn{1}{|c|}{ Quality strategy } \\
\hline 1 & $\begin{array}{l}\text { product innovation (trought technology driven solutions), product performance improving, product design } \\
\text { development, support diversification in new models and variant; }\end{array}$ \\
\hline 2 & service innovation, services evolution; \\
\hline 3 & technological innovation; new technology implementation; \\
\hline 4 & use of new material and techniques, use of innovative / green materials; \\
\hline 5 & new production process (new raw materials, new manufacturers, recycling, ecc); \\
\hline 6 & integration of new distribution channels, specific distribution channel enhancement; \\
\hline 7 & $\begin{array}{l}\text { service level and time to market improvement, development of best in class service around revolutionary } \\
\text { ideas; }\end{array}$ \\
\hline 8 & after sales evolution, customer service's model innovation; \\
\hline 9 & customer relations evolutions; \\
\hline
\end{tabular}


TABLE 4 - Efficiency Strategy from the Business Plans analyzed

\begin{tabular}{|c|c|}
\hline \multicolumn{2}{|r|}{ Business Strategies Classification } \\
\hline \multicolumn{2}{|r|}{ Efficiency strategy } \\
\hline 1 & Costs: synergies and savings \\
\hline & $\begin{array}{l}\text { Improving in sourcing efficiency, optimization of procurement / sourcing activity, energy, logistics and } \\
\text { personnel savings; cost synergies leverage, economies of scope and scale, supply contracts renegotiation, } \\
\text { operational efficiency, obtain scale benefits, distribution channel efficiency, product cost reduction, } \\
\text { alternative materials \& compound introduction; }\end{array}$ \\
\hline 2 & Operations optimization and Business Process reengineering \\
\hline & $\begin{array}{l}\text { Sales management optimization, pricing optimization, service model optimization, operational machine } \\
\text { strengthening, activities centralization, bringing in house activities currently outsourced, branch reduction, } \\
\text { reduction on "branch new openings" plan, reduction/elimination of duplications in activities, best practices } \\
\text { introduction, service model optimization, network redesign, simplification on process, IT programs; }\end{array}$ \\
\hline 3 & Plant utilization \\
\hline & $\begin{array}{l}\text { Plant efficiency increasing, industrial efficiency; use of low cost manufacturing unit optimization, supply } \\
\text { source diversification; }\end{array}$ \\
\hline & Workforce Management and Productivity \\
\hline & $\begin{array}{l}\text { Leverage on flexibility, personnel productivity and turnover, sales network rationalization, workforce } \\
\text { reduction, higher flexibility of labor costs; }\end{array}$ \\
\hline
\end{tabular}

TABLE 5 - Communication Strategy from the Business Plans analyzed

\begin{tabular}{|r|l|}
\hline \multicolumn{2}{|c|}{ Business Strategies Classification } \\
\hline 1 & \multicolumn{1}{|c|}{ Communication strategy } \\
\hline 2 & Leverage premium brand, improvement on brand images and awareness, maintain strong brand \\
\hline 3 & Digital marketing; \\
\hline 4 & Social networking; \\
\hline 5 & Evolution from customer satisfaction to customer experience; \\
\hline 6 & Elevate in store experience; \\
\hline
\end{tabular}

TABLE 6 - Support Strategy from the Business Plans analyzed

\section{Business Strategies Classification} Support strategy

1 Exploitation of opportunities coming from new laws;

2 Incentive mechanism to support the market; 


\section{THE MACRO RESULTS}

Looking at the 26 Business Plans of the FTSE MIB companies we can conclude that:

- The entrepreneurial attitude hardly exists. Indeed the creation of a new industry (a new market, made primarily by new products/services) is never stated.

- Innovation is generally approached as "marginal improvement" on existing products/services (working on technologies, raw materials, functionalities, design, etc);

- Strategies for growth are confined to existing industries (geographic expansion and diversification on adjacent business areas);

- Strategies for quality are developed with a low innovation rate (use of model already applied);

- Strategy for efficiency are highly utilized;

- Strategy for communication and the use of external support is scarcely expressed in the Business Plans examined.

FIGURE 2 - "Value Life Cycle Model": best mix of strategies vs analysis results

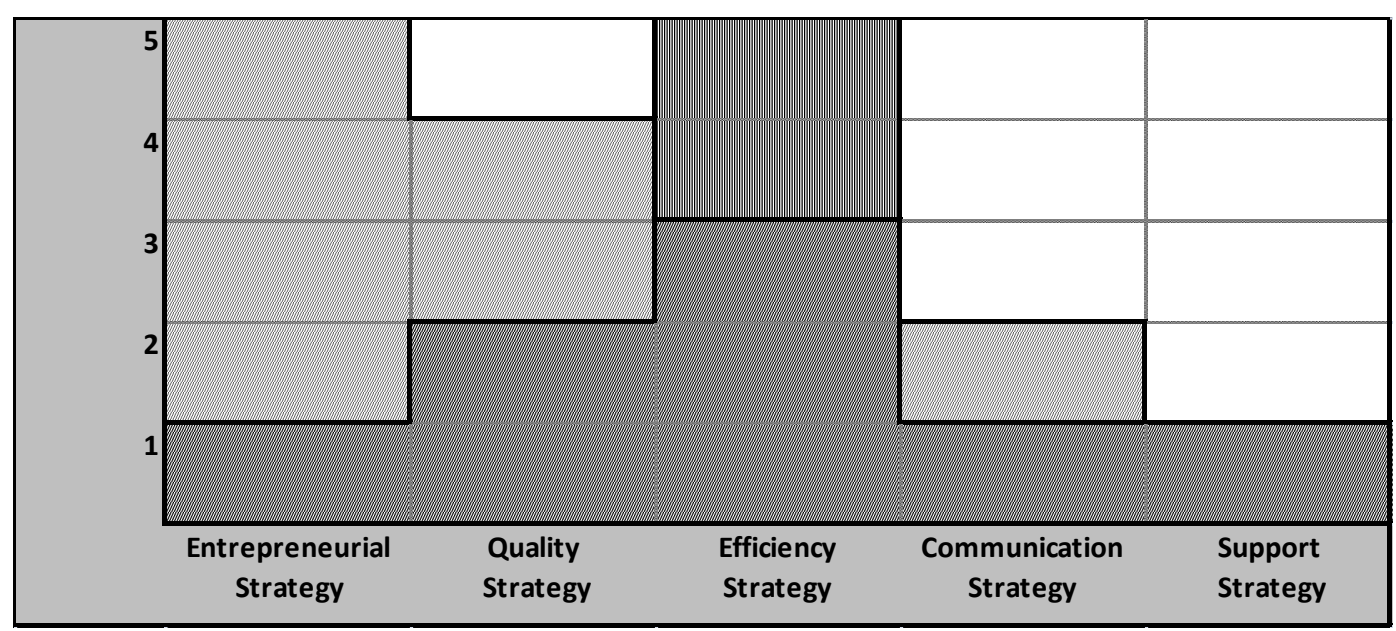




\section{CONCLUSIONS}

The overall result shows that the FTSE MIB Companies don't have a strategic goal of creating new industries.

The innovation level inside the business strategies designed by the companies is generally very low.

The strategic focus of the FTSE MIB Companies is inside the industry, on the competitive environment.

Most of the business strategies undertaken by the companies are internally focused (process optimization, personnel productivity, production flexibility, cost efficiency and revenue management).

The FTSE MIB Companies aren't creating a new future. Following competition and competiveness the entrepreneurial system seems to be only able to see a marginal optimization on existing products / services.

We are seeing the effect of these competitive strategy all over Italy: lot of companies are going to death. The society ask for economic growth rate, rise on employment and high investment flow, that only entrepreneurial strategy can develop. Without the development of new industries, it's hard to expect economic and social growth.

It is reasonable to expect from the FTSE MIB Companies strategic plans the maximum level of innovation capability. But, looking to the future planned by them, it seems that no new products nor services are at the horizon.

We expect a future radically new. The only way to get it is the use of new knowledge on both the strategic and organization side.

CSE Crescendo is hardly working on new knowledge sciences. The "Value Life Cycle Model" is one of the analysis method developed on strategy. Our role to build a new future is the diffusion of the most innovative knowledge over the entrepreneurial and social systems by new analysis method and development processes. 


\section{BIBLIOGRAPHY}

C.BILTON, S.CUMMINGS, Creative Strategy: Reconnecting Business and Innovation, Wiley \& Sons, Chichester 2010.

M.BLASONE, P.JIZBA, G.VITIELLO, Quantum Field Theory and Its Macroscopic Manifestations, Imperial College Press, London, 2011.

D.BOHM, B.J.HILEY, The Undivided Universe, Routledge, New York, NY, 1993.

S.CUMMINGS, D.WILSON, Images of Strategy, Blackwell Publishing, Malden, MA, 2003.

G. S.DAY, D. J.REIBSTEIN, R. E.GUNTHER, Wharton On Dynamic Competitive Strategy, John Wiley, New York, NY, 1997.

A.F.DE TONI, A.BARBARO, Visione Evolutiva, Etas Libri, Milano 2010.

E.DEL GIUDICE, 2010, Una via quantistica alla teoria dei sistemi, in Ulivi, L. (Ed.), Strutture Di Mondo Il Pensiero Sistemico Come Specchio Di Una Realtà Complessa, Il Mulino, Bologna, Mondo, 2010. pp. 47-70.

E.FREEMAN, A Stakeholder Approach to Strategic Management, Pitman, London, 2001.

D. FOGG, Team-Based Strategic Planning, CreateSpace, Charleston, SC, 2010.

A.GODINO, R.CANESTRARI, La psicologia scientifica: nuovo trattato di psicologia generale, CLUEB Bologna, 2007.

A.C.HAX, N.S.MAJLUF, Direzione strategica (Strategic management), IPSOA, Milano, 1998.

A.S.HUFF (ed.), Mapping Strategic Thought, New York, NY, John Wiley, 1990. 